\title{
The transpressional connection between Dom Feliciano and Kaoko Belts at 580-550 Ma
}

\author{
Pedro Oyhantçabal $\cdot$ Siegfried Siegesmund • \\ Klaus Wemmer $\cdot$ Cees W. Passchier
}

Received: 10 October 2009/Accepted: 20 July 2010/Published online: 9 August 2010

(c) The Author(s) 2010. This article is published with open access at Springerlink.com

\begin{abstract}
A new U-Pb SHRIMP age of $551 \pm 4$ Ma on a mylonitic porphyry that intruded into the Sierra Ballena Shear Zone (Southernmost Dom Feliciano Belt, Uruguay) and a review of relevant published data make possible a more refined correlation and reconstruction of Brasiliano/ Pan-African transpressional events. Paleogeographic reconstruction, kinematics and timing of events indicate a connection between the shear systems of the Dom Feliciano and Kaoko Belts at 580-550 Ma. Sinistral transpression recorded in shear zones accommodates deformation subsequent to collision between the Congo and Río de la Plata Cratons. The correlation is strengthened by the similarity of magmatic and metamorphic ages in the Coastal Terrane of the Kaoko Belt and the Punta del Este Terrane of the Dom Feliciano Belt. This post-collisional sinistral transpression
\end{abstract}

P. Oyhantçabal $(\bowtie)$

Departamento de Geología-Facultad de Ciencias,

Universidad de la República, Iguá 4225,

11400 Montevideo, Uruguay

e-mail: oyhantca@fcien.edu.uy

S. Siegesmund · K. Wemmer

Geoscience Centre of the Georg-August

University Göttingen, Goldschmidtstr. 3,

37077 Göttingen, Germany

e-mail: ssieges@gwdg.de

K. Wemmer

e-mail: kwemmer@gwdg.de

C. W. Passchier

Institut für Geoswissenschaften,

JohannesGutenburg University,

55099 Mainz, Germany

e-mail: cpasschi@mail.uni-mainz.de brought these units near to their final position in Gondwana and explains the different evolution at 550-530 Ma. While in the Kaoko Belt, an extensional episode resulted in exhumation as a consequence of collision in the Damara Belt, in the Dom Feliciano Belt, sinistral transpression occurred associated with the closure of the southern Adamastor Ocean due to Kalahari-Río de la Plata collision.

Keywords Dom Feliciano Belt · Kaoko Belt · Brasiliano · Pan-African · Transpressional deformation . Shear Zones

\section{Introduction}

The Neoproterozoic amalgamation of West Gondwana resulted from the convergence of the Río de la Plata, Kalahari and Congo Cratons (Fig. 1) and the formation of three orogenic belts in southern Africa, the Kaoko, Gariep and Damara Belts, respectively, and the associated Dom Feliciano Belt in the southern part of South America (Porada 1989; Prave 1996; Dürr and Dingeldey 1996). Porada (1979) already suggested a link between the Dom Feliciano Belt of South America and the Kaoko and Gariep Belts of southwestern Africa. In this paper, we present new data that support this link.

Effects of sinistral transpressional deformation during Brasiliano/Pan-African events have been found in the Dom Feliciano as well as in the Kaoko Belt (Fernandes et al. 1992; Dürr and Dingeldey 1996). Transpressional structures and central orogen transcurrent shear zones are major features controlling the architecture and evolution of both belts indicating oblique convergence of the Río de la Plata and Congo Cratons (Dürr and Dingeldey 1996; Fernandes and Koester 1999; Goscombe et al. 2003; 


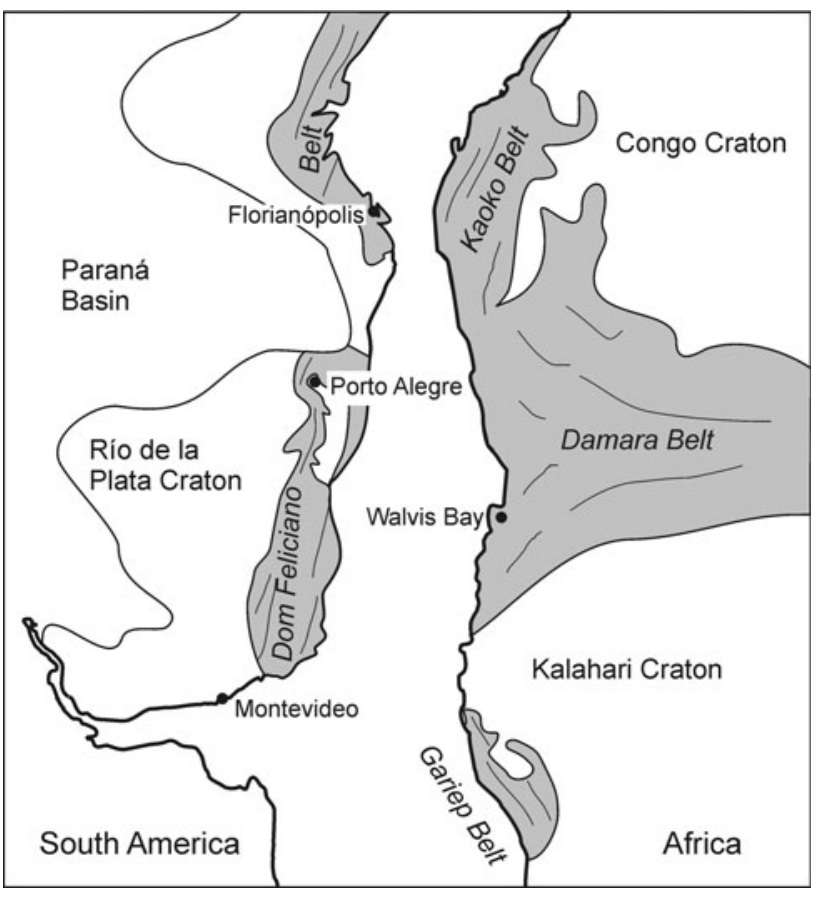

Fig. 1 Tectonic sketch map of Gondwana showing the positions of the cratonic nuclei and orogenic belts

Konopásek et al. 2005; Oyhantçabal et al. 2009a). During the last decade, a considerable amount of new data on both belts has been gathered, so that a better correlation of units and events between South American and African geology is now possible. Several recent structural and geochronological investigations in the southern Dom Feliciano Belt (Basei et al. 2005, 2008; Oyhantçabal et al. 2007, 2009a, b; Gross et al. 2009) and in the Kaoko Belt (Goscombe et al. 2003, 2005; Konopásek et al. 2005, 2008; Goscombe and Gray 2008; Foster et al. 2009) should help to constrain the tectonic evolution. Exhumation in orogens can be related to extrusion of blocks during transpression (Thompson et al. 1997) or to extension (Dewey 2002), therefore, available exhumation data should also be considered when reconstructing the evolution of an orogen.

Oyhantçabal (2005) indicated the possibility of a connection between the shear zones of the Kaoko and Dom Feliciano Belts. Later, de Wit et al. (2008) presented a tectonic map of Brasiliano/Pan-Africano structures in Africa and South America and emphasized the identical Neoproterozoic age and the potential connection or "piercing points" that these major subvertical shear zones represent, being therefore one of the prime targets for further geochronological and structural investigations. The aim of this paper is to discuss the correlation between tectonic events and associated shear zones in the Kaoko and Dom Feliciano Belts. This correlation enhances our understanding of the evolution of the Pan-African/Brasiliano orogenic system.

\section{Geological framework}

Dom Feliciano Belt (Uruguay and Southern Brazil)

The Dom Feliciano Belt (DFB) extends for more than $1,200 \mathrm{~km}$ from southern Uruguay to Santa Catarina State in Brazil. Several shear zones cross this belt, the most prominent of which are the Sierra Ballena (SBSZ) in Uruguay, and the Dorsal de Canguçu (DCSZ) and Major Gercinho (MGSZ) in southern Brazil (Fig. 2).

Three main geotectonic units are recognized in the Dom Feliciano Belt (Basei et al. 2000) from east to west (Fig. 2):

The Granite Belt comprises high- $\mathrm{K}$ calc-alkaline and subordinate peraluminous, and alkaline metaluminous granitoids. Most of the intrusions display a distinct relation with the main shear zones. The geochemical signature of this granitic magmatism suggests a post-collisional setting with slab break-off and lithosphere delamination as possible associated mechanisms (Bitencourt and Nardi 2000; Oyhantçabal et al. 2007). The age of the Granite Belt ranges between 630 and $600 \mathrm{Ma}$ according to available $\mathrm{U}-\mathrm{Pb}$ ages (SHRIMP and conventional).

The Schist Belt is a fold and thrust belt and comprises pre-collisional Neoproterozoic metavolcanic-sedimentary sequences. The metamorphic grade of these sequences reaches greenschist to lower amphibolite facies. The Lavalleja Group of Uruguay and the equivalent Porongos (Rio Grande do Sul) and Brusque (Santa Catarina) Groups of south Brazil are the lithostratigraphic units defined for this schist belt. Detrital zircon grains gave a maximum Neoproterozoic age for these sequences (Basei et al. 2008).

The Foreland Belt consists of several volcano-sedimentary and sedimentary successions of Ediacaran age (Gaucher 2000; Gaucher et al. 2003, 2004 and Pecoits et al. 2008), including marine to continental transition deposits (Arroyo del Soldado and Maldonado Groups in Uruguay and the Itajaí and Camaquã Basins in Brazil).

In the easternmost Dom Feliciano Belt, a pre-Brasiliano Basement Inlier, the Punta del Este Terrane (PET), consists of gneisses, migmatites and granulites of Neoproterozoic age (Oyhantçabal et al. 2009b). East of this basement, the low-grade meta-sedimentary rocks of the Rocha Group (Uruguay) have been associated with the Gariep Belt in Namibia, based on their provenance signature (Basei et al. 2005, 2008). Oyhantçabal et al. (2009b) recently reported new SHRIMP ages for the Punta del Este Terrane indicating a magmatic event at ca. $770 \mathrm{Ma}$ followed by highgrade metamorphism at ca. $640 \mathrm{Ma}$. These magmatic and metamorphic ages suggest a connection between the Punta del Este Terrane of the Dom Feliciano Belt and the Coastal Terrane of the Kaoko Belt (Oyhantçabal et al. 2009b; Gross et al. 2009). The magmatic ages (850-750 Ma) in the Damara and Kaoko belts have been associated with a 


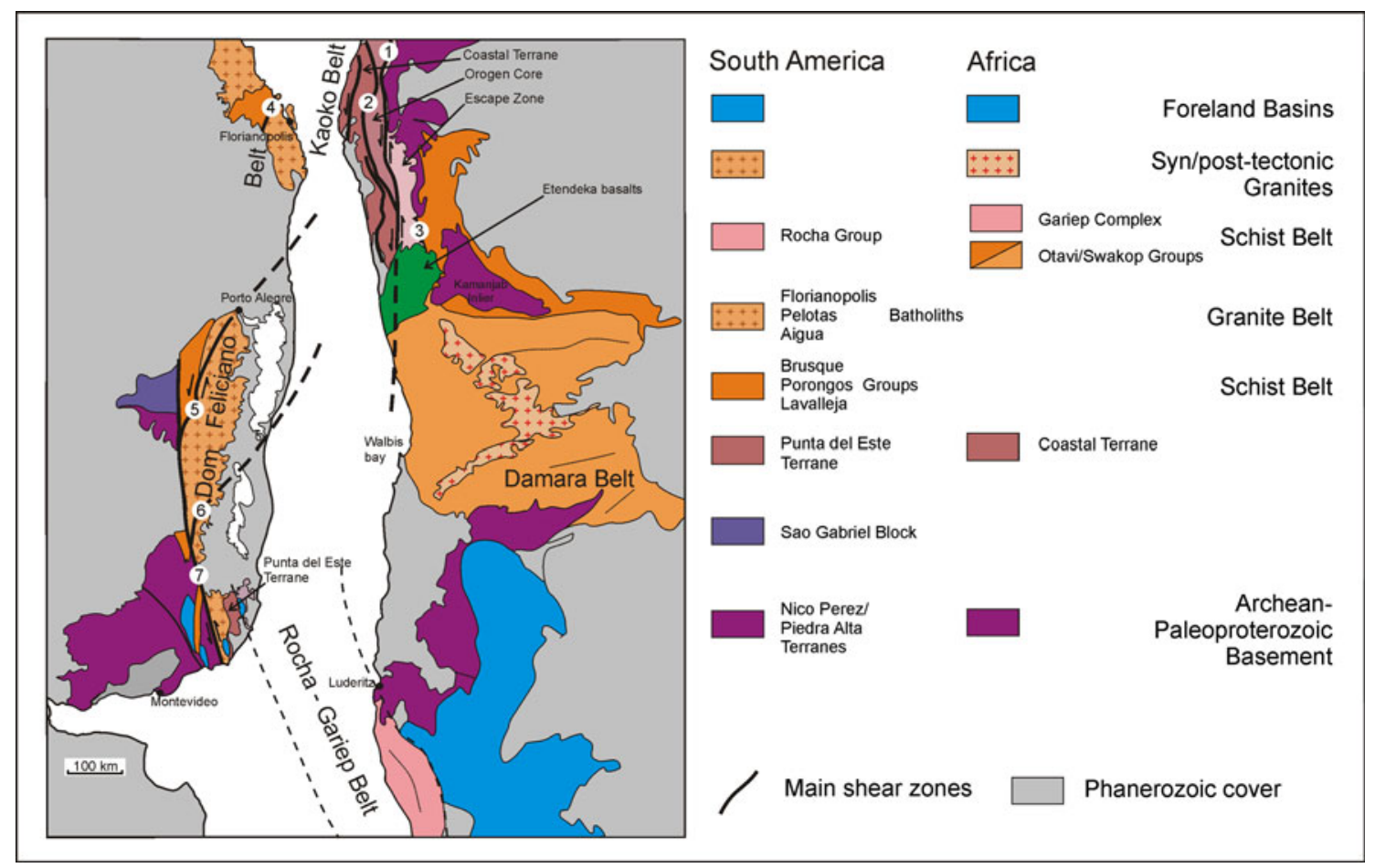

Fig. 2 Sketch map of the main units of the Brasiliano and PanAfrican Orogens. South American side based on data from Basei et al. (2000, 2005); Hartmann et al. (2001, 2002); Silva et al. (2005); Philipp and Machado (2005) and Oyhantçabal et al. (2007, 2009a and b). South African side based on data from Gray et al. (2006); Goscombe and Gray (2008) and Gray et al. (2008). Main shear zones: (1) Purros, (2) Three Palms, (3) Sesfontein thrust, (4) Major Gercino,

(5) Dorsal de Canguçu, (6) Cerro Amaro, (7) Sierra Ballena pre-collisional rifting stage (Porada 1989; Prave 1996; Hoffmann et al. 2004; Konopásek et al. 2008).

Kaoko Belt (Namibia and Angola, Southwestern Africa)

The Kaoko Belt is divided into four main NNW-trending zones (Miller 1983; Goscombe et al. 2003; Konopásek et al. 2005; Goscombe and Gray 2008) bounded by three main lineaments, the Three Palms Shear Zone, the Purros Shear Zone and the Sesfontein Thrust (Fig. 2).

- The Eastern Zone comprises shelf carbonates of a foreland basin with low grade to very low grade metamorphism (Hoffman et al. 1998, cited by Goscombe et al. 2003; Konopásek et al. 2005). Deformation here is simple, with E-directed thrusting and associated folding of the sediments.

- The Central Kaoko Zone ("Escape zone" of Goscombe et al. 2005), west of the Sesfontein Thrust, is an inverted Barrovian metamorphic sequence in a complex alternation of igneous and sedimentary metamorphic rocks. Careful mapping, summarized by Goscombe and Gray (2008), revealed that part of the material is Paleoproterozoic basement, covered with a series of
Neoproterozoic sediments. Deformation and metamorphism are intense and hamper separation of basement and cover. The basic structure, however, is one of nappes displaced to the east and separated from the Eastern zone by a low angle low grade to brittle fault zone, the Sesfontein Thrust.

- The Orogen Core (inboard Western Kaoko Zone of Goscombe and Gray 2007), located between Purros and Three Palms shear zones, includes Barrovian style metamorphic sequences and Mesoproterozoic basement inliers (Miller 1983; Seth et al. 1998; Konopásek et al. 2005; Goscombe and Gray 2007) and is dominated by strike slip tectonics.

- The Coastal Terrane comprises meta-sedimentary sequences with low pressure upper amphibolite metamorphism and Neoproterozoic I-type intrusions, indicating an arc-type setting with an age of 660-640 Ma (Konopásek et al. 2005; Goscombe et al. 2005). The coastal terrane and orogenic core are together also referred to as the "Western Zone" (Konopásek et al. 2005). The Coastal Terrane, however, shows evidence of a metamorphic cycle around 655-645 Ma, which is different from any other in the Kaoko Belt, indicating that it is part of an exotic terrain that docked to the developing Kaoko Belt in the latest Neoproterozoic. A 
major strike slip shear zone, the Three Palms Shear Zone, separates the coastal terrane from the Central Zone. The suture zone, where the Coastal Terrane docked with the rest of the Kaoko Belt, sometime within the interval of $645-580 \mathrm{Ma}$, seems to be located between Three Palms and Purros shear zones and is probably masked by granitic intrusions (Goscombe et al. 2005; Konopásek et al. 2008).

The main transpressional event in the Kaoko Belt is associated with collision, transpressional deformation and emplacement of S-type granitoids at $\sim 580-570 \mathrm{Ma}$. Cessation of transpressional deformation is constrained by post-kinematic pegmatites at ca. $530 \mathrm{Ma}$ (Goscombe et al. 2005).

\section{Main Brasiliano/Pan-African shear zones of the Kaoko and Dom Feliciano Belts}

The Sierra Ballena shear zone of the Dom Feliciano Belt

The Sierra Ballena Shear Zone (SBSZ) is part of a highstrain transcurrent system that divides the Dom Feliciano Belt into two different domains. Major associated shear zones (see Fig. 2) are the Dorsal de Canguçu and Major Gercinho systems (in Río Grande do Sul and Santa Catarina of Brazil, respectively). Poor outcrop conditions away from the coast hamper exact reconstruction of the relation between these zones. The SBSZ is a NNW-SSE zone, ca $4 \mathrm{~km}$ wide, cropping out for more than $250 \mathrm{~km}$ with a steep foliation orientation. Stretching lineations show a shallow plunge to the SSW, and the kinematic regime is a sinistral oblique reverse motion (Oyhantçabal et al. 2009a). Four different kinds of mylonitic rocks have been recognized in the zone.

Granitic mylonites are the most widespread rock type and display a strongly foliated matrix wrapped around alkali feldspar and plagioclase porphyroclasts. Gradual transitions from protomylonite and mylonite to ultramylonite are observed. Syntectonic granites are normally the protolith of these mylonites and solid-state microstructures slightly to completely overprint magmatic features (Oyhantçabal et al. 2009a). Similar microstructures were described by Tommasi et al. (1994) from the Dorsal de Canguçu Shear Zone.

Phyllonites contain small rounded porphyroclasts of feldspar in a very fine-grained and finely banded matrix rich in muscovite and biotite laths. Gradual transitions between granitic mylonite and phyllonite are observed and suggest that these phyllonites were derived from granitic mylonites through comminution of feldspar and retrograde alteration to phyllosilicates due to the influx of water (Oyhantçabal et al. 2009a). Similar alterations are observed in other large shear zones (e.g. Imber et al. 1997).

Quartz mylonite, probably developed from quartz veins emplaced in the SBSZ, is common. Recrystallization in quartz includes subgrain rotation recrystallization and grain boundary migration.

Mylonitic porphyries represent the fourth kind of mylonite in the SBSZ. New chemical and geochronological data are presented in this paper on these porphyries as described in detail in the next section.

The microstructures present in the mylonites of the SBSZ are indicative of recovery and recrystallization in quartz by subgrain rotation and grain boundary migration under upper greenschist to lower amphibolite facies metamorphic conditions. Microstructures in feldspar are typical of deformation at mid to upper greenschist facies metamorphic conditions. A retrograde evolution during deformation is indicated for the SBSZ (Oyhantçabal et al. 2009a) as well as for the Dorsal de Canguçu Shear Zone (Tommasi et al. 1994).

\section{Mylonitic porphyries}

Mylonitic porphyries are the most unusual feature of the SBSZ. They were emplaced as dikes in the granitic mylonites and phyllonites and evolved to mylonites during later shearing and associated folding. The texture is porphyritic (Fig. 3) with residual phenocrysts (deformed to porphyroclasts) of alkali feldspar and quartz in a finegrained and banded matrix. Na-amphibole is the most

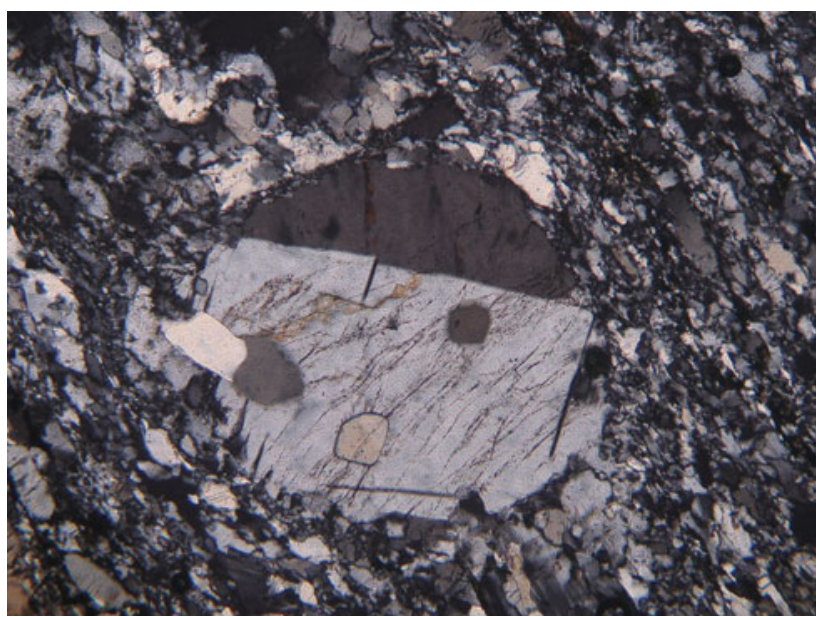

Fig. 3 Microstructural features of the mylonitic porphyries of the SBSZ. Sample UY5-05, section cut perpendicular to foliation and parallel to lineation. Feldspar porphyroclast (residual phenocryst), in foliated matrix. Crossed polarized light, width of view $1.8 \mathrm{~mm}$ 
Table 1 Whole-rock major and trace element compositions of the mylonitic porphyries of Sierra Ballena shear zone

\begin{tabular}{|c|c|c|c|c|c|c|c|c|c|c|c|c|c|}
\hline Sample & $\mathrm{SiO}_{2}$ & $\mathrm{TiO}_{2}$ & $\mathrm{Al}_{2} \mathrm{O}_{3}$ & $\mathrm{Fe}_{2} \mathrm{O}_{3}$ & $\mathrm{MnO}$ & $\mathrm{MgO}$ & $\mathrm{CaO}$ & $\mathrm{Na}_{2} \mathrm{O}$ & $\mathrm{K}_{2} \mathrm{O}$ & $\mathrm{P}_{2} \mathrm{O}_{5}$ & $\mathrm{CO}_{2}$ & $\mathrm{H}_{2} \mathrm{O}$ & Total \\
\hline \multicolumn{14}{|c|}{ Major elements } \\
\hline SB091 & 75.8 & 0.20 & 10.5 & 3.93 & 0.007 & 0.17 & 0.34 & 2.90 & 4.88 & 0.05 & 0.39 & $<0.01$ & 99.17 \\
\hline SB111 & 75.3 & 0.14 & 11.1 & 2.97 & 0.04 & 0.11 & 0.30 & 2.82 & 6.13 & 0.03 & 0.40 & 0.16 & 99.50 \\
\hline SB030 & 71.2 & 0.20 & 15.4 & 1.43 & 0.01 & 0.46 & 1.32 & 5.37 & 3.07 & 0.15 & 0.55 & 0.04 & 99.20 \\
\hline SB171 & 73.3 & 0.09 & 14.8 & 1.25 & 0.03 & 0.31 & 1.15 & 4.24 & 3.05 & 0.10 & 0.87 & 0.01 & 99.20 \\
\hline Sample & $\mathrm{Ba}$ & & $\mathrm{Cr}$ & $\mathrm{Ga}$ & $\mathrm{Nb}$ & $\mathrm{Rb}$ & $\mathrm{Sc}$ & $\mathrm{Sr}$ & V & & Y & $\mathrm{Zn}$ & $\mathrm{Zr}$ \\
\hline \multicolumn{14}{|c|}{ Trace elements } \\
\hline SB091 & 138 & & 426 & 31 & 115 & 187 & 10 & 10 & 12 & & 170 & 224 & 1,807 \\
\hline SB111 & 12 & & 531 & 34 & 99 & 382 & 10 & 12 & 10 & & 168 & 250 & 963 \\
\hline SB030 & 2,628 & & 44 & 23 & 10 & 46 & 11 & 1,711 & 21 & & 10 & 53 & 147 \\
\hline SB171 & 946 & & 39 & 19 & 15 & 109 & 10 & 270 & 10 & & 10 & 51 & 82 \\
\hline
\end{tabular}

frequent mafic mineral, occurring as fine needles (about $0.02 \mathrm{~mm}$ in length), occasionally associated with aegirineaugite.

The fine-grained matrix of these dikes indicate subvolcanic emplacement. Evidence of dynamic recrystallization in feldspar, together with the occurrence of aegirine-augite in pressure shadows, suggest that deformation of these mylonitic porphyries began in the magmatic stage and continued in the solid state.

Geochemistry of the mylonitic porphyries

Analysis of major and trace elements for 4 samples of the mylonitic porphyries is presented in Table 1. Major element concentrations were determined by X-ray fluorescence (XRF), while the trace element concentrations were determined by ICP-MS at the laboratories of the Geoscience Centre of the University of Göttingen (Germany). The samples show high silica contents ranging from 71 to 76 wt $\%$, suggesting the possibility of silica enrichment during mylonitization. $\mathrm{K}$ contents are high $\left(\mathrm{K}_{2} \mathrm{O}=3.1-4.9 \mathrm{wt} \%\right)$, and the rocks plot in the transalkaline field of Middlemost (1997). Shand's (1943) alumina and alkali saturation molar ratios indicate compositions in the transition between the metaluminous and peralkaline fields.

Using immobile elements, these rocks classify as trachyte and alkali rhyolite in the $\mathrm{Nb} / \mathrm{Y}$ versus $\mathrm{Zr} / \mathrm{Ti}$ diagram (Pearce 1996), and the $\mathrm{Nb} / \mathrm{Y}$ ratio (ca. 1) indicates a transitional affinity between alkaline and subalkaline series (Fig. 4). Despite these few samples are not conclusive, the geochemical affinity is compatible with a post-collisional alkaline suite. In the $\mathrm{Rb}$ versus $\mathrm{Y}+\mathrm{Nb}$ and $\mathrm{Nb}$ versus $\mathrm{Y}$ diagrams of Pearce et al. (1984), devised for granitoid rocks, the mylonitic porphyries plot in a scattered region, two in VAG field and two in WPG field (Fig. 5).

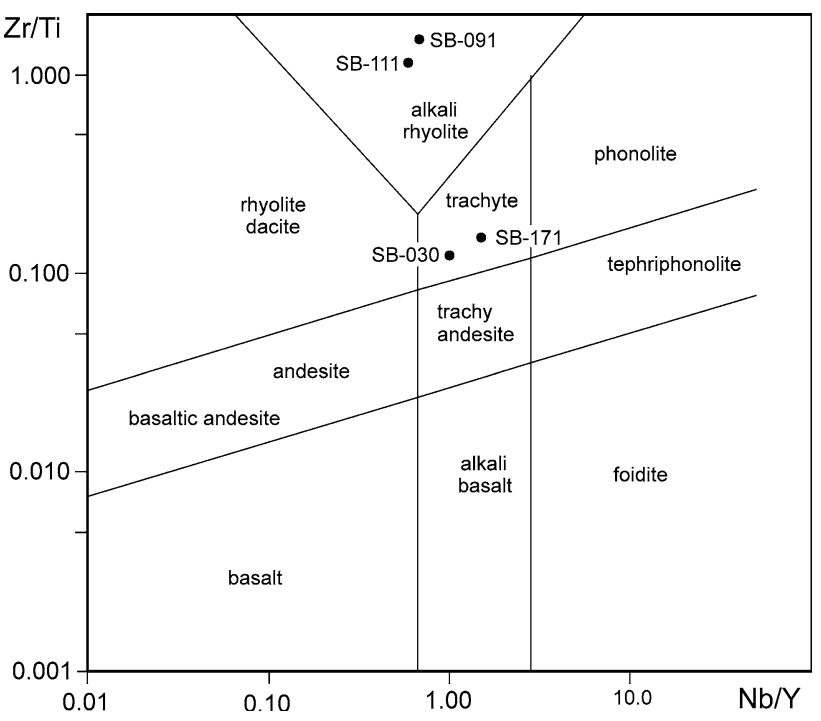

Fig. $4 \mathrm{Nb} / \mathrm{Y}$ versus $\mathrm{Zr} / \mathrm{Ti}$ diagram (Pearce 1996) for the mylonitic porphyries

$\mathrm{U}-\mathrm{Pb}$ SHRIMP geochronology of the mylonitic porphyries

$\mathrm{U}-\mathrm{Pb}$ analyses of zircon grains from mylonitic porphyry were made using the SHRIMP II instrument at the Research School of Earth Sciences, ANU, Australia. The coordinates of the sample locality are $32^{\circ} 36^{\prime} 27.60^{\prime \prime} \mathrm{S}$ and $54^{\circ} 14^{\prime} 7.43^{\prime \prime} \mathrm{W}$ (datum WGS84), and the geological location is shown in Fig. 6. Ages are reported with their twosigma uncertainties (95\% confidence level). Results are given in the Table 2.

Sample UY5-05 is a fine-grained, dark-colored mylonite with small pyroxene and amphibole porphyroclasts. At the microscopic scale, a fine-grained banded matrix $(0.1-0.2 \mathrm{~mm})$ composed of quartz, perthitic orthoclase and 
Fig. $5 \mathrm{Rb}$ versus $\mathrm{Y}+\mathrm{Nb}$

(a) and $\mathrm{Nb}$ versus $\mathrm{Y}$

(b) diagrams of Pearce et al.

(1984) for the mylonitic

porphyries
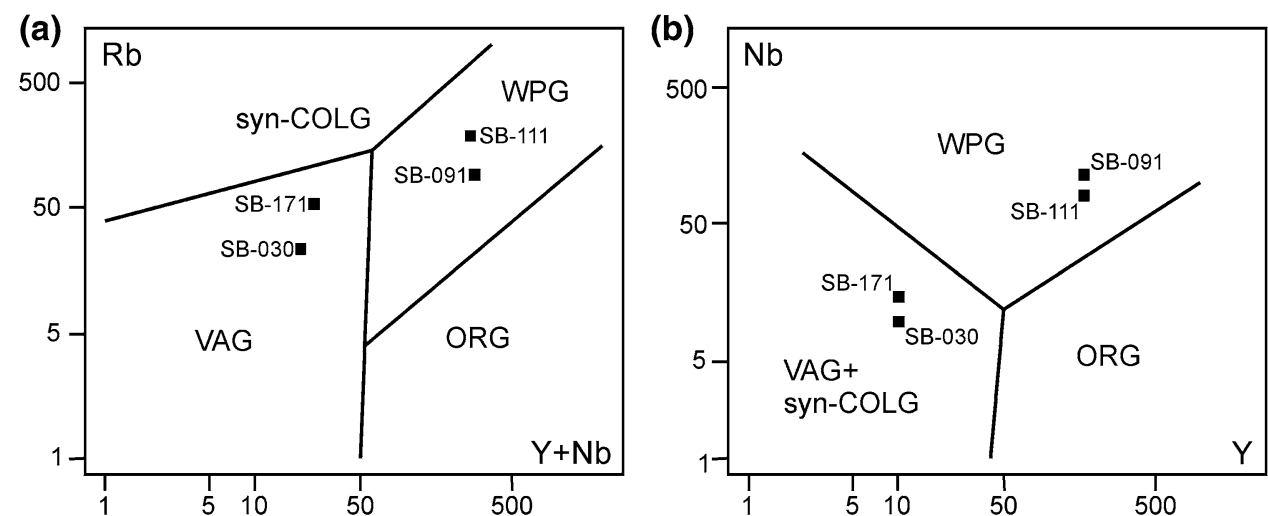

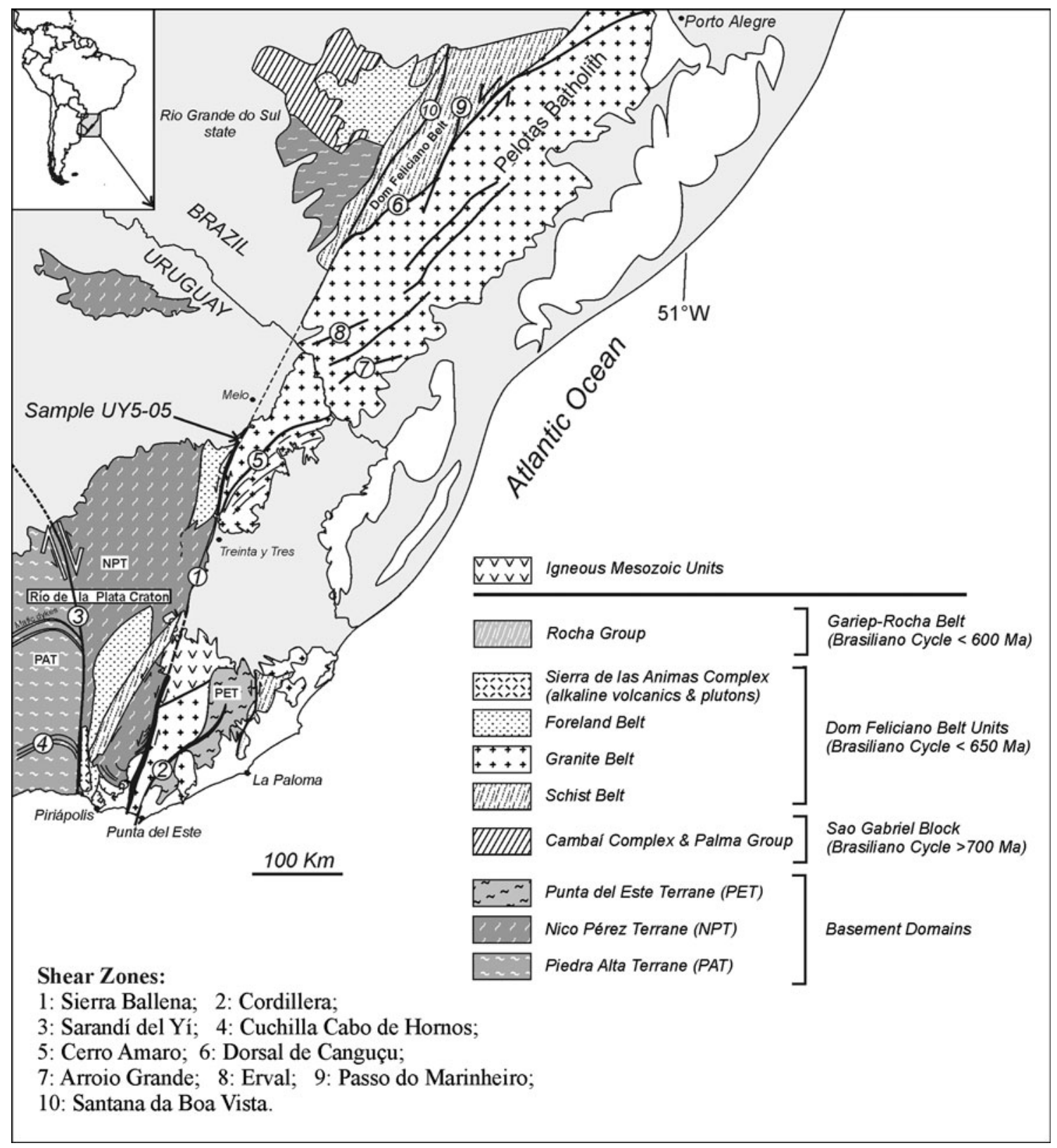

Fig. 6 Location of sample UY5-05 on a regional geological map of the southern Dom Feliciano Belt (modified from Oyhantçabal et al. 2009a) 


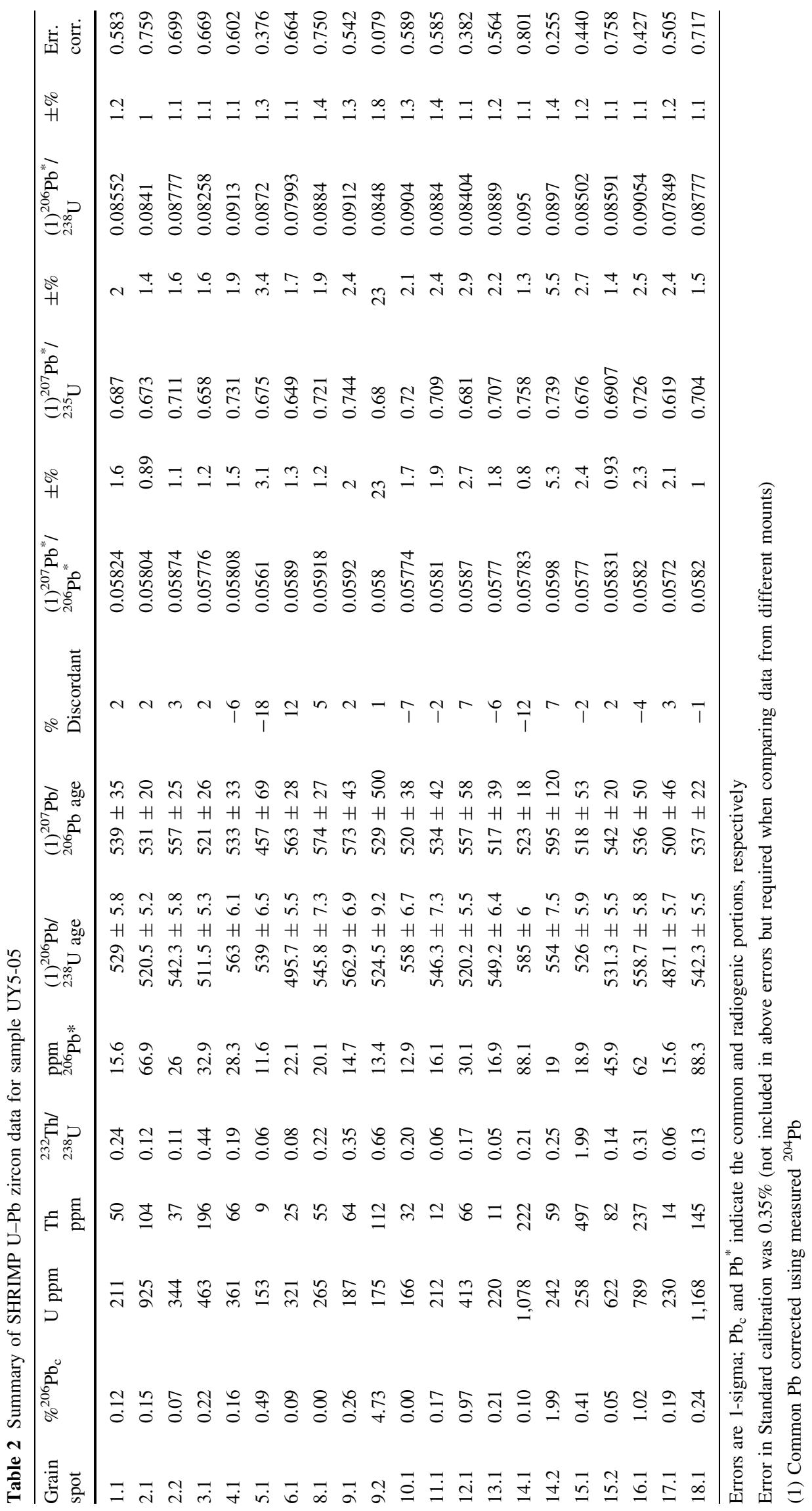




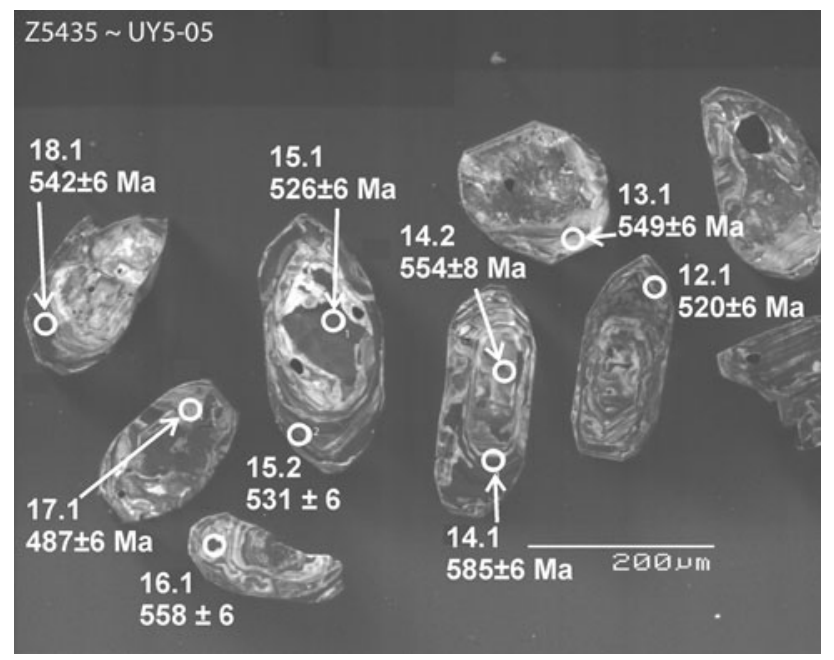

Fig. 7 Cathodoluminescence image of representative zircon grains form the sample UY5-05

dark-green blue amphibole needles is observable. The porphyroclasts are relictic phenocrysts of orthoclase, aegirine-augite and hornblende (about $1.0-1.5 \mathrm{~mm}$ ), rounded and flattened (Fig. 3).

The zircon crystals of sample UY5-05 are euhedral, normal prismatic to stubby and brown. The length/width ratio is rather constant (ca. 3:1). Spectacular oscillatory zoning typical of magmatic crystallization and complex swirling zoning and patchy development of bright and dark zones is observable in cathodoluminescence images (Fig. 7).

A total of 21 points in 18 grains were measured. The data yield a near-concordant, upper intercept age of $537 \pm 12 \mathrm{Ma}(\mathrm{MSWD}=0.43$, probability of fit $=0.98$, $n=21$; Fig. 8 a). The points also yielded an identical weighted mean ${ }^{207} \mathrm{~Pb}-{ }^{206} \mathrm{~Pb}$ age of $537 \pm 13$ (95\% conf.; MSWD $=0.44$, probability $=0.98, n=21$ ). Assuming that $\mathrm{Pb}$-loss gives the spread down of points along the concordia, after rejection of 10 points, a concordia age of $551 \pm 4.4 \mathrm{Ma}(95 \%$ conf.; MSWD $=1.18$, probability $=$
$0.28, n=11$ ) is obtained (Fig. 8 b). This is the preferred age for the crystallization of these porphyries.

Age constraints for Sierra Ballena shear zone

Nucleation of the shear zones and the onset of the transpressional deformation are estimated based on the ages of associated syntectonic intrusions at 658 to $605 \mathrm{Ma}$ (Frantz et al. 2003 and Oyhantçabal et al. 2007, 2009a).

After an extensional or transtensional episode (at ca. $590 \mathrm{Ma}$ ), a second transpressional episode is constrained by the ${ }^{40} \mathrm{Ar} /{ }^{39} \mathrm{Ar}$ cooling age of muscovite from quartz mylonite (586 $\pm 2 \mathrm{Ma}$; Oyhantçabal et al. 2009a) and the age of the syntectonic Maldonado granite $(564 \pm 7 \mathrm{Ma}$; U-Pb SHRIMP on zircon; Oyhantçabal et al. 2009b). The age of the alkaline magmatism associated with the mylonitic porphyries is $551 \pm 4 \mathrm{Ma}$ (U-Pb on zircon, this investigation). Quartz mylonites and mylonitic porphyries are spatially associated along the SBSZ. These data indicate cooling and closure of muscovite in the quartz mylonites occurred before the emplacement of the porphyries, and therefore, an exhumation episode older than $551 \mathrm{Ma}$ is suggested.

For a review of the other major shear zones of the Dom Feliciano Belt, the reader is referred to Passarelli et al. (2010, this volume).

\section{The shear zones of the Kaoko Belt}

The Sesfontein, Purros (PSZ) and Three Palms shear zones (the last one equivalent to the Village Mylonite Zone of Goscombe et al. 2003 and Konopásek et al. 2005) are the main structures of the Kaoko transpressional belt (Fig. 2). All three structures are crustal scale shear zones of localized flow, although some branching is observed.

The Three Palms shear zone is 1 to $2 \mathrm{~km}$ wide and dominantly vertical. Stretching lineations show a shallow plunge to SSE indicating oblique extensional strike slip. The deformation conditions are typical exhumation during shear, and PT estimates show an evolution form
Fig. 8 U-Pb Concordia plots of SHRIMP data on zircon for sample UY5-05: a Model 1 solution on 21 points; b Concordia age on 11 points. Data symbolized with gray ellipses were rejected in age calculation. Ellipses represent $1 \sigma$ errors
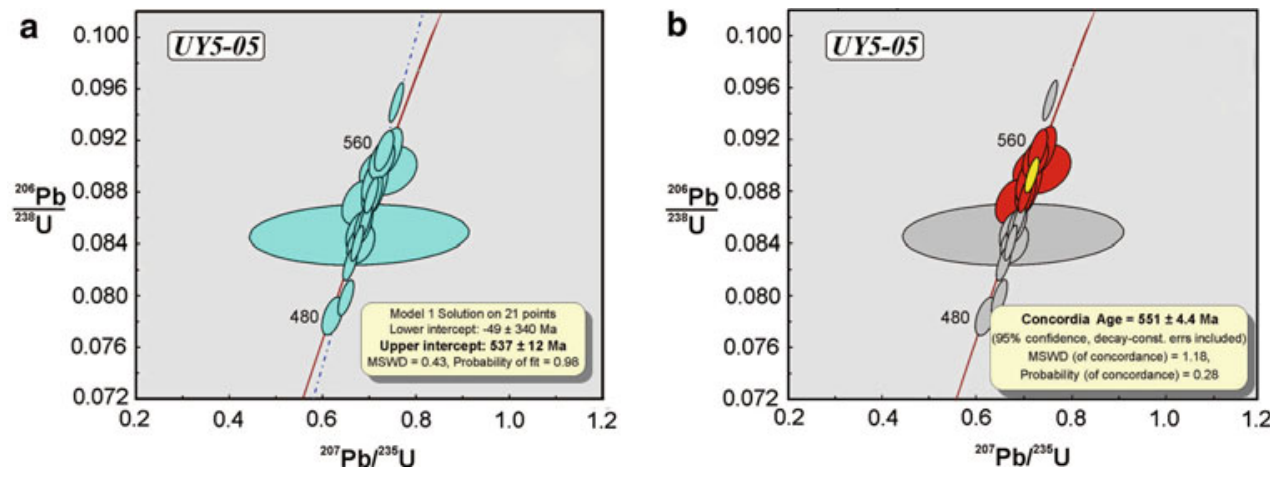
$555-545^{\circ} \mathrm{C}, 4-4.8 \mathrm{~kb}$ through $580-450^{\circ} \mathrm{C}$ and finally brittle overprint under $290^{\circ} \mathrm{C}$ (Foster et al. 2009).

The Purros shear zone is 1 to $5 \mathrm{~km}$ wide and seems to have a west-dipping listric shape, with steep orientations in the north and shallower orientations in the south (Goscombe et al. 2005). Stretching lineations plunge to NNW, and therefore, kinematics is oblique reverse. The deformation conditions do not show contrast with the country rock, and overprinting by low-temperature deformation is very scarce. PT estimates for deformation are $640^{\circ} \mathrm{C}-8.8 \mathrm{~kb}$, 620-580 ${ }^{\circ} \mathrm{C}, 4.4-4.6 \mathrm{~kb}$ (Foster et al., 2009). The Sesfontein shear zone is west dipping with dominantly shallow dip and low-grade mylonitic to brittle deformation structures.

The kinematics of the three shear zones as indicated by the orientation of aggregate lineations and shear sense indicators is laterally variable. The Sesfontein shear zone operated by thrusting to the east toward the foreland at low grade. The oldest fabrics in the belt are gently plunging foliations and lineations, presumably associated with westdipping subduction that caused docking of the coastal terrane after $600 \mathrm{Ma}$ (Goscombe et al. 2005). The suture, located between the Three Palms and Purros shear zones, is probably masked by the Boundary Igneous Complex (Konopásek et al. 2008). The Purros and Three Palms shear zones overprint this fabric and were established later and are now dominantly sinistral strike slip shear zones with a component of thrusting in the Purros shear zone, based on gently N-plunging lineations, and a extensional component in the Three Palms shear zone, with gently south-plunging lineations.

Foster et al. (2009) point out that structures and metamorphic assemblages show evidence of retrograde juxtaposition of HT-medium P in the Orogen core and HP-moderate T inverted Barrovian metamorphism in the Central Zone and therefore favor differential exhumation during oblique extension instead of the extrusion of the Orogen Core during transpression as suggested previously by Goscombe and Gray (2008). Ar-Ar data in the Three Palms, Khumib and Village shear zones indicate this differential exhumation occurred at 530-520 Ma and is probably associated with the final closure of the Damara Belt (Foster et al. 2009).

\section{Tectonic evolution and the transpressional connection between Dom Feliciano and Kaoko Belts}

Pre-collisional magmatism and HT metamorphism in the Coastal terrane of the Kaoko Belt and in the Punta de Este Terrane of the Dom Feliciano Belt

In the reconstruction of the Pre-Atlantic ocean, the present Dom Feliciano Belts of Uruguay and the Kaoko Belt of
Namibia are opposite and close together, separated by an obscured zone of possibly several hundred $\mathrm{km}$ wide, presently below the shelves of South America and Africa. Magmatism at 850-750 Ma has been indicated in the Punta del Este Terrane of the Dom Feliciano Belt and in the Coastal Terrane of the Kaoko Belt, suggesting a connection between both Terranes (Oyhantçabal et al. 2009b). This range of magmatic ages has been associated with pre-collisional rifting in Damara and Kaoko belts (Porada 1989; Prave 1996; Hoffmann et al. 2004; Konopásek et al. 2008). High-temperature metamorphism at 650-600 Ma confirms the suggested connection (Gross et al. 2009; Oyhantçabal et al. 2009b).

Calc-alkaline magmatism with arc affinity, recorded between 660 and $650 \mathrm{Ma}$ in the Coastal Terrane (Masberg et al. 2005; Goscombe et al. 2005) and between 650 and $600 \mathrm{Ma}$ in the Granite Belt of the Dom Feliciano Belt (Frantz et al. 2003; Oyhantçabal et al. 2007, 2009b), supports westward subduction and suggests the above-mentioned HT metamorphism probably occurred in the root of a magmatic arc. In this tectonic scenario, the Schist Belt of the DFB (Fig. 2) can be interpreted as the back arc, as suggested by Jost and Bitencourt (1980) and SánchezBettucci et al. (2001).

Exhumation and deposition of molasse deposits in the DFB

Available cooling ages on muscovite from pegmatite dikes of the Punta del Este Terrane indicate cooling below 300-400 ${ }^{\circ}$ at ca. $620 \mathrm{Ma}$ (Oyhantçabal et al. 2009b). This early exhumation in the South American side is consistent with the deposition of the Ediacaran sedimentary sequences of Arroyo del Soldado and Maldonado Groups (Gaucher et al. 2003; Pecoits et al. 2008) and is probably related to exhumation after the collision of the magmatic arc with the Rio de la Plata Craton. There is no record up to now of this event on the African side.

Post-collisional transpressional magmatism and deformation in the Kaoko and Dom Feliciano Belts

Magmatism related to transcurrent transpressional tectonics at 580-550 Ma is well documented in both belts. In the Solís de Mataojo granite of Uruguay (584 $\pm 13 \mathrm{Ma}$; $\mathrm{Pb}-\mathrm{Pb}$ on titanite; Oyhantçabal et al. 2007), meso and microstructures, formed during transitions from magmatic to solid-state, are evidence of flattening and sinistral shearing (Oyhantçabal et al. 2001). Similar flattening structures, but with evidence for east-side up kinematics, were observed in the Maldonado Granite $(564 \pm 7 \mathrm{Ma}$; U-Pb SHRIMP on Zircon; Oyhantçabal et al. 2009b), on the eastern side of the Sierra Ballena Shear Zone (Figs. 2 and 6). 
Syn- to post-kinematic S-type granites, with ages in the range 580-550 Ma, are frequent in the Coastal Terrane and the westernmost Orogen Core (Seth et al. 1998; Franz et al. 1999; Kröner et al. 2004; Goscombe et al. 2005). The age of this magmatism corresponds to the post-collisional transpressional stage (580-550 Ma; Goscombe and Gray 2008; Konopásek et al. 2008).

Extension and exhumation in the Kaoko Belt

According to Foster et al. (2009), exhumation and juxtaposition of high- and low- pressure domains in the Kaoko Belt occurred between 530 and $525 \mathrm{Ma}$, after the main transpressive event, by oblique extension associated with the closure of the Damara Belt. A correlative extensional event on the South American side was not reported. The U-Pb SHRIMP age of the mylonitic porphyries presented in this investigation could represent the record of this event, considering the suggested within-plate affinity, but further investigation is necessary. A possible explanation of the difference observed between Kaoko and southern Dom Feliciano Belts at $530-520 \mathrm{Ma}$ is that the main sinistral transpressional phase (580-550 Ma) had already brought the units near to their final position in the Gondwana supercontinent, and therefore, the far-field effect of the closure of the Damara Belt was different.

In the southern Dom Feliciano Belt, the final amalgamation of Gondwana resulted in the closure of the Rocha-Gariep Basin in Ediacaran times, as a consequence of the collision of Kalahari and Río de la Plata Cratons (Frimmel and Frank 1998; Frimmel and Fölling 2004; Basei et al. 2005). This late event in the evolution of the Brasiliano Cycle probably represents a second orogenic event, younger than the Dom Feliciano orogeny. The closure of the Rocha-Gariep Belt (550-540 Ma; Frimmel and Frank 1998; Basei et al. 2005, 2008) should be responsible of the folding observed in the mylonitic porphyries of Sierra Ballena Shear Zone and in the final structure of SBSZ (Oyhantçabal et al. 2009a). For a sketch of the proposed evolution, see Fig. 9. Schmitt et al. (2008) reported a 530-490 Ma tectono-metamorphic event, the Búzios Orogeny, in the Cabo Frio tectonic domain of Rio de Janeiro (Brazil). This event is a late collision associated with the final assembly of Gondwana and is probably coeval with the extension recorded in the Kaoko Belt and the closure of Damara, taking into account the different trends of these orogens (Fig. 1 in Schmitt et al. 2008).

\section{Conclusions}

A review of recently published data for Dom Feliciano and Kaoko Belts reveals the following main points:

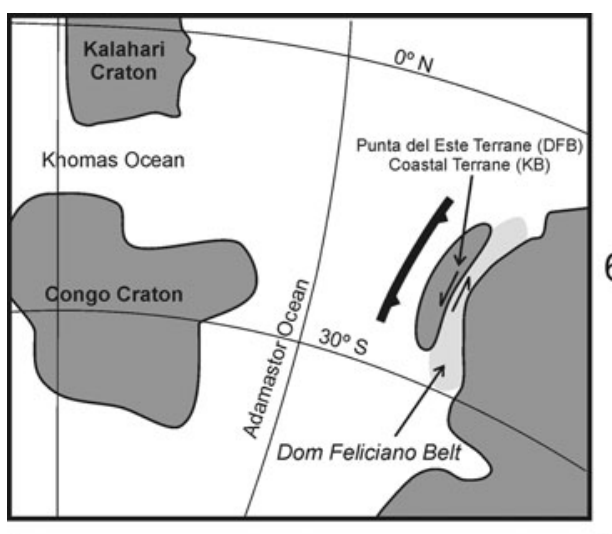

$650-600 \mathrm{Ma}$

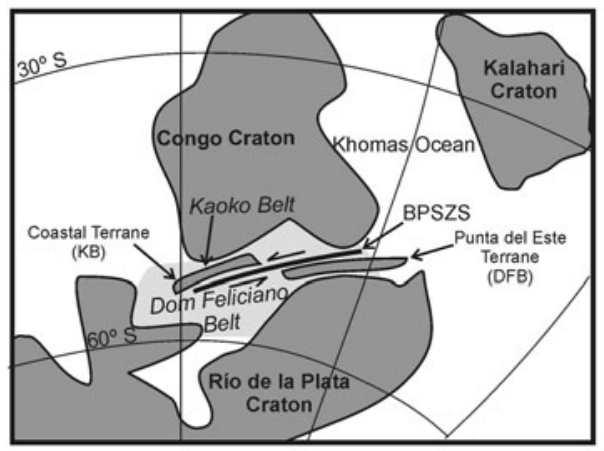

$580-550 \mathrm{Ma}$

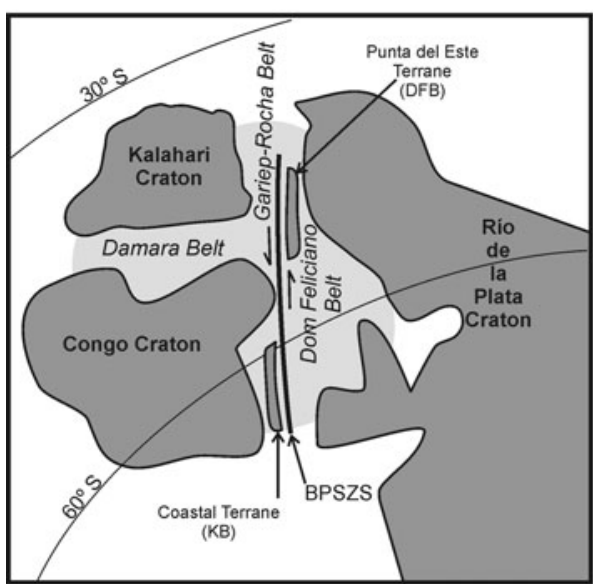

$550-500 \mathrm{Ma}$

Fig. 9 Proposed evolution. Schema based on Figs. 8 to 10 of Gray et al. (2008) slightly modified to show the Punta del Este Terrane of the Dom Feliciano Belt and the Coastal Terrane of the Kaoko Belt. BPSZS, Ballena-Purros Shear Zone System

1. Magmatic ages at $850-750 \mathrm{Ma}$ and metamorphic peak at ca. $650 \mathrm{Ma}$ indicate a connection between the Coastal Terrane of the Kaoko Belt and the Punta del Este Terrane of the Dom Feliciano Belt. Both terranes were probably part of one single continental magmatic arc that collided with the Río de La Plata Craton closing the back arc basin of the Schist Belt (Lavalleja, Porongos and Brusque groups). The age of this collision is poorly constrained between 650 and $600 \mathrm{Ma}$, based on high $\mathrm{T}$ metamorphic peak. 
2. Collision of the Río de la Plata Craton (including the Schist and Granite Belts, and the Punta del Este Terrane of the Dom Feliciano Belt) with the Congo Craton resulted in post-collisional transpression at 580-550 Ma in the Kaoko and Dom Feliciano Belts.

3. The post collisional sinistral transpression at 580-550 Ma brought the units near to their final position in Gondwana, and therefore, the influence of Damara and Gariep orogenies was different. This sinistral transpression and separation of the Coastal Terrane of the Kaoko Belt and the Punta del Este Terrane of the Dom Feliciano imply that the Sierra Ballena-Purros system produced a final displacement over several $100 \mathrm{~km}$. While in the Kaoko Belt, an extensional episode resulted in exhumation between 520 and $524 \mathrm{Ma}$ as a consequence of collision in the Damara Belt (Foster et al. 2009), in the Dom Feliciano Belt, sinistral transpression occurred associated with the closure of the southern Adamastor Ocean.

Acknowledgments P. Oyhantçabal gratefully acknowledges grants provided by the German Academic Exchange Service (DAAD, proposal A/06/00572), the German Science Foundation (DFG, GZ: SI 438/32-1) and CSIC-UdelaR (Comisión Sectorial de Investigación Científica de la Universidad de la República) for research visits to the Geoscience Centre of the Georg-August University Göttingen. The authors thank K. Simon (Abt. Geochemie, GZG Göttingen) and R. Naumann (GFZ Potsdam) for geochemical analyses and R. Armstrong for SHRIMP age determinations. Renata Schmitt and Hartwig Frimmel are thanked for their helpful and constructive reviews.

Open Access This article is distributed under the terms of the Creative Commons Attribution Noncommercial License which permits any noncommercial use, distribution, and reproduction in any medium, provided the original author(s) and source are credited.

\section{References}

Basei MAS, Siga O Jr, Masquelin H, Harara OM, Reis Neto JM, Preciozzi F (2000) The Dom Feliciano Belt (Brazil-Uruguay) and its Foreland (Rio de la Plata Craton): framework, tectonic evolution and correlations with similar terranes of southwestern Africa. In: Cordani U, Milani E, Thomaz Filho A, Campos D (eds) Tectonic evolution of South America, 31st International Geological Congress. Rio de Janeiro, Brazil, pp 311-334

Basei MAS, Frimmel HE, Nutman AP, Preciozzi F, Jacob J (2005) A connection between the Neoproterozoic Dom Feliciano (Brazil/ Uruguay) and Gariep (Namibia/South Africa) orogenic beltsevidence from a reconnaissance provenance study. Precambr Res 139:195-221

Basei MAS, Frimmel HE, Nutman AP, Preciozzi F (2008) West Gondwana amalgamation based on detrital zircon ages from Neoproterozoic Ribeira and Dom Feliciano belts of South America and comparison with coeval sequences from SW Africa. In: Pankhurst RJ, Trouw RAJ, Brito Neves BB, De Wit MJ (eds) West Gondwana: Pre-Cenozoic correlations across the South Atlantic Region. Geological society, vol 294. Special Publications, London, pp 239-256
Bitencourt MF, Nardi LVS (2000) Tectonic setting and sources of magmatism related to the southern Brazilian shear belt. Revista Brasileira de Geociências 30:186-189

da Silva LC, McNaughton NJ, Armstrong R, Hartmann LA, Fletcher IR (2005) The Neoproterozoic Mantiqueira Province and its African connections: a zircon-based $\mathrm{U}-\mathrm{Pb}$ geochronologic subdivision for the Brasiliano/Pan-African systems of orogens. Precambr Res 136:203-240

De Wit MJ, Stankiewicz J, Reeves C (2008) Restoring Pan-AfricanBrasiliano connections: more Gondwana control, less TransAtlantic corruption. Geological Society, vol 294. Special Publications, London, pp 399-412. doi:10.1144/SP294.20

Dewey J (2002) Transtension in Arcs and Orogens. Int Geol Rev 44:402-439. doi:10.2747/0020-6814.44.5.402

Dürr SB, Dingeldey DP (1996) The Kaoko Belt (Namibia): part of a late Neoproterozoic continental-scale strike-slip system. Geology 24:503-506

Fernandes LAD, Koester E (1999) The Neoproterozoic Dorsal de Canguçu strike-slip shear zone: its nature and role in the tectonic evolution of southern Brazil. J Afr Earth Sci 29:3-24

Fernandes LAD, Tommasi A, Porcher CC (1992) Deformation patterns in the Southern Brazilian branch of the Dom Feliciano belt: a reappraisal. J S Am Earth Sci 5:76-84

Foster DA, Goscombe BD, Gray DR (2009) Rapid exhumation of deep crust in an obliquely convergent orogen: the Kaoko Belt of the Damara Orogen, Tectonics, 28, TC4002. doi:10.1029/ 2008TC002317

Frantz JC, McNaughton NJ, Marques JC, Hartmann LA, Botelho NF, Caravaca G (2003) Shrimp U-Pb zircon ages of granitoids from southernmost Brazil: constraints on the temporal evolution on the Dorsal de Canguçu transcurrent shear zone and the eastern Dom Feliciano Belt. IV S Am Symp Isotope Geol 1:174-177

Franz L, Romer RL, Dingeldey DP (1999) Diachronous Pan-African granulite-facies metamorphism (650 Ma and $550 \mathrm{Ma}$ ) in the Kaoko belt, NW Namibia. Eur J Mineral 11:167-180

Frimmel HE, Fölling PG (2004) Late Vendian closure of the Adamastor Ocean: timing of tectonic inversion and syn-orogenic sedimentation in the Gariep Basin. Gondwana Res 7:685-699

Frimmel HE, Frank W (1998) Neoproterozoic tectono-thermal evolution of the Gariep Belt and its basement, Namibia/South Africa. Precambr Res 90:1-28

Gaucher C (2000) Sedimentology, palaeontology and stratigraphy of the Arroyo del Soldado group (Vendian to Cambrian, Uruguay). Beringeria 26:1-120

Gaucher C, Boggiani PC, Sprechmann P, Sial AN, Fairchild T (2003) Integrated correlation of the Vendian to Cambrian Arroyo del Soldado and Corumbá Groups (Uruguay and Brazil): palaeogeographic, palaeoclimatic and palaeobiologic implications. Precambr Res 120:241-278

Gaucher C, Chiglino L, Pecoits E (2004) Southernmost exposures of the Arroyo del Soldado Group (Vendian to Cambrian, Uruguay): paleogeographic implications for the amalgamation of W.Gondwana. Gondwana Res 7:701-714

Goscombe BD, Gray DR (2007) The coastal Terrane of the Kaoko Belt, Namibia: outboard arc-terrane and tectonic significance. Precambr Res 155:139-158

Goscombe BD, Gray D (2008) Structure and strain variation at midcrustal levels in a transpressional orogen: a review of Kaoko Belt structure and the character of West Gondwana amalgamation. Gondwana Res 13:45-85

Goscombe BD, Hand M, Gray D (2003) Structure of the Kaoko Belt, Namibia: progressive evolution of a classic transpressional orogen. J Struct Geol 25:1049-1081

Goscombe BD, Gray DR, Armstrong RA, Hand M, Mawby J (2005) Event geochronology of the Pan-African Kaoko Belt, Namibia. Precambr Res 140:103.e1-103.e41 
Gray DR, Foster DA, Goscombe B, Passchier CW, Trouw RAJ (2006) ${ }^{40} \mathrm{Ar} /{ }^{39} \mathrm{Ar}$ thermochronology of the Pan-African Damara Orogen, Namibia, with implications for tectonothermal and geodynamic evolution. Precambr Res 150:49-72

Gray DR, Foster DA, Meert JG, Goscombe BD, Armstrong R, Trouw RAJ, Passchier CW (2008) A Damara orogen perspective on the assembly of southwestern Gondwana. In: Pankhurst RJ, Trouw RAJ, Brito Neves BB, De Wit MJ (eds) West Gondwana: PreCenozoic correlations across the South Atlantic Region. Geological Society, vol 294. Special Publications, London, pp 257-278. doi:10.1144/SP294.14

Gross AOMS, Droop GTR, Porcher CC, Fernandes LAD (2009) Petrology and thermobarometry of mafic granulites and migmatites from the Chafalote Metamorphic Suite: new insights into the Neoproterozoic P-T evolution of the Uruguayan-Sul-RioGrandense Shield. Precambr Res 170:157-174

Hartmann LA, Campal N, Santos JO, McNaughton N, Bossi J, Schipilov A, Lafon JM (2001) Archean crust in the Río de la Plata Craton, Uruguay-SHRIMP U-Pb zircon reconnoissance geochronology. J S Am Earth Sci 14:557-570

Hartmann LA, Santos JO, Bossi J, Campal N, Schipilov A, McNaughton N (2002) Zircon and Titanite U-Pb SHRIMP geochronology of Neoproterozoic felsic magmatism on the eastern border of the Río de la Plata Craton, Uruguay. J S Am Earth Sci 15:229-236

Hoffman PF, Kaufman AJ, Halverson GP, Schrag DP (1998) A neoproterozoic snowball earth. Science 281:1342-1346

Hoffmann K-H, Condon DJ, Bowring SA, Crowley JL (2004) U-Pb zircon date from the Neoproterozoic Ghaub Formation, Namibia: constraints on Marinoan glaciation. Geology 32:817-820

Imber J, Holdsworth RE, Butler CA, Lloyd GE (1997) Fault-zone weakening processes along the reactivated Outer Hebrides Fault Zone, Scotland. J Geol Soc Lond 154:105-109

Jost H, Bitencourt MF (1980) Estratigrafia e tectônica de uma fração da Faixa de Dobramentos Tijucas no Rio Grande do Sul. Acta Geol Leop 11(7):27-59

Konopásek J, Kröner S, Kitt SL, Passchier CW, Kröner A (2005) Oblique collision and evolution of large-scale transcurrent shear zones in the Kaoko belt, NW Namibia. Precambrian Res 136:139-157

Konopásek J, Kosler J, Tajcmanovál L, Ulrich S, Kitt SL (2008) Neoproterozoic igneous complex emplaced along major tectonic boundary in the Kaoko Belt (NW Namibia): ion probe and LA-ICP-MS dating of magmatic and metamorphic zircons. J Geol Soc 165:153-165

Kröner S, Konopásek J, Kröner A, Passchier CW, Poller U, Wingate MTD, Hofmann KH (2004) U-Pb and $\mathrm{Pb}-\mathrm{Pb}$ zircon ages for metamorphic rocks in the Kaoko Belt of Northwestern Namibia: a Palaeo- to Mesoproterozoic basement reworked during the Pan-African orogeny. S Afr J Geol 107:455-476

Masberg P, Mihm D, Jung S (2005) Major and trace element and isotopic ( $\mathrm{Sr}, \mathrm{Nd}, \mathrm{O})$ constraints for Pan-African crustally contaminated grey granite gneisses from the southern Kaoko belt, Namibia. Lithos 84:25-50

Middlemost EAK (1997) Magmas, Rocks and Planetary Development. Longman, Harlow, p 299

Miller RMCG (1983) The Pan-African Damara Orogen of Namibia. In: RMCG. Miller (ed.), Evolution of the Damara Orogen of south west Africa/Namibia. Special Publication of the Geological Society of South Africa 11, 431-515

Oyhantçabal P (2005) The Sierra Ballena Shear zone: kinematics, timing and its significance for the geotectonic evolution of southeast Uruguay. http://webdoc.sub.gwdg.de/diss/2005/oyhantcabal_cironi/ oyhantcabal_cironi.pdf
Oyhantçabal P, Heimann A, Miranda S (2001) Measurement and interpretation of strain in the syntectonic Solís de Mataojo granitic complex, Uruguay. J Struct Geol 23:807-817. doi: 10.1016/S0191-8141(00)00152-8

Oyhantçabal P, Siegesmund S, Wemmer K, Frei R, Layer P (2007) Postcollisional transition from calc-alkaline to alkaline magmatism during transcurrent deformation in the southernmost Dom Feliciano Belt (Braziliano-Pan-African, Uruguay). Lithos 98:141-159

Oyhantçabal P, Siegesmund S, Wemmer K, Layer P (2009a) The Sierra Ballena Shear Zone in the southernmost Dom Feliciano Belt (Uruguay): evolution, kinematics, and deformation conditions. Int J Earth Sci. doi:10.1007/s00531-009-0453-1

Oyhantçabal P, Siegesmund S, Wemmer K, Presnyakov S, Layer P (2009b) Geochronological constraints on the evolution of the southern Dom Feliciano Belt (Uruguay). J Geol Soc Lond 166:1075-1084

Passarelli C, Basei MAS, Siga Jr O, Wemmer K, Oyhantcabal P (2010) Major shear zones of southern Brazil and Uruguay: escape tectonics in the eastern border of Rio de La Plata and Paranapanema cratons during the Western Gondwana amalgamation. Int J Earth Sci, this volume

Pearce JA (1996) A user's guide to basalt discrimination diagrams. In: Wyman DA (ed) Trace Element Geochemistry of Volcanic Rocks: applications for massive sulphide exploration, vol 12 . Geological Association of Canada, Short Course Notes, Canada, pp 79-113

Pearce JA, Harris NW, Tindle AG (1984) Trace element discrimination diagrams for the tectonic interpretation of granitic rocks. J Petrol 25:956-983

Pecoits E, Gingras M, Aubet N, Konhauser K (2008) Ediacaran in Uruguay: palaeoclimatic and palaeobiological implications. Sedimentology 55:689-719

Philipp RP, Machado R (2005) The late Neoproterozoic granitoid magmatism of the Pelotas Batholith, southern Brazil. J S Am Earth Sci 19:461-478

Porada H (1979) The Damara-Ribeira Orogen of the Pan-AfricanBrasiliano cycle in Namibia (Southwest Africa) and Brazil as interpreted in terms of continental collision. Tectonophysics $57: 237-265$

Porada H (1989) Pan-African rifting and orogenesis in southern equatorial Africa and eastern Brazil. Precambr Res 44:103-136

Prave AR (1996) Tale of three cratons: Tectonostratigraphic anatomy of the Damara orogen in northwestern Namibia and the assembly of Gondwana. Geology 24:1115-1118

Sánchez Bettucci L, Cosarinsky M, Ramos VA (2001) Tectonic setting of the late Proterozoic Lavalleja Group (Dom Feliciano Belt), Uruguay. Gondwana Res 4(3):395-407

Schmitt RS, Trouw RAJ, Van Schmus WR, Passchier CW (2008) Cambrian orogeny in the Ribeira Belt (SE Brazil) and correlations within West Gondwana: ties that bind underwater. Geological Society, vol 294. Special Publications, London, pp 279-296. doi:10.1144/SP294.15

Seth B, Kröner A, Mezger K, Nemchin AA, Pidgeon RT, Okrusch M (1998) Archaean to Neoproterozoic magmatic events in the Kaoko belt of NW Namibia and their geodynamic significance. Precambr Res 92:341-363

Shand HS (1943) Eruptive rocks. Wiley and Sons, New York, p 444

Thompson AB, Schulmann K, Jezek J (1997) Thermal evolution and exhumation in obliquely convergent (transpressive) orogens. Tectonophysics 280:171-184

Tommasi A, Vauchez A, Fernandes LAD, Porcher CC (1994) Orogen-parallel strike-slip faulting and synkinematic magmatism in the Dom Feliciano Belt, Southern Brazil. Tectonics $13: 421-437$ 